\title{
Religion and Identity in James Joyce's A Portrait of the Artist as a Young Man
}

\section{Catherina Akca \\ Kafkas University}

"All that is solid melts into air, all that is holy is profaned" (Marx and Engels, 1854, cited in Childs, 2000: 31-32). These words are evocative of the loss of faith and certainty, the sense of fragmentation and alienation, and the atmosphere of dissolution which pervaded much of western European society from the middle of the nineteenth century. Since Comte's philosophy of positivism and Darwin's theory of evolution had challenged confidence in religious authority, the undermining of faith which appeared in western culture during this period was to be expected. The crisis of faith continued, concurrent with increasing urbanisation, industrialisation, mechanisation, and the alienation contingent upon capitalism, until for many people any residual belief in a divinely ordered, meaningful universe was finally laid to rest amid the waste and carnage of World War I. (Childs, 2000: 46-48, 55)

On the other hand, the Roman Catholic Church continued to be a potent force in Joyce's native Ireland throughout and beyond the nineteenth century, not only in terms of the doctrinal and spiritual guidance it provided but also because of the influence it exerted upon the cultural and political life of the country. Roman Catholicism had long been a focus of nationalist resistance against English colonialism, such that "Irishness had come to be seen by many as synonymous with 
Catholicism" (Belanger, 2001: xx-XII). The Irish Ireland movement ${ }^{1}$ proclaimed that "Ireland's authentic cultural nationalist identity was unquestionably as a Gaelic and Catholic nation" (Brown, cited in Belanger, 2001: xxII). In some literary quarters, any Irish work "that claimed to be 'national' would be judged according to whether or not it conformed to the stereotype which ascribed to Catholic Ireland the virtues of purity, innocence, and sanctity" (Lyons, cited in Mulrooney, 2001). However, the Irish nationalist community was itself divided. On the one hand, people like Dante Riordan in A Portrait of the Artist as a Young Man (Joyce, 1992) proclaimed that Irish identity was inseparable from Catholicism. They argued that priests had a duty to guide their flocks in matters of politics and "public morality" such as the Parnell affair, in which the former hero of the nationalist cause was pilloried for his adultery. On the other hand, people like Simon Dedalus and Mr Casey argued that the Catholic Church had betrayed Irish nationalism all too often and that it should no longer interfere in Irish politics: "We have had too much God in Ireland. Away with God!" (28).

James Joyce himself had renounced Catholicism, objecting to the interference of the Church in Irish politics (Belanger, 2001: vi), and rejecting its attitude to sexual morality: "I left the Catholic Church, hating it most fervently. I found it impossible for me to remain in it on account of the impulses of my nature." Joyce, cited in Ellmann, 1984: 1). In correspondence, he wrote that his series of short stories, Dubliners, was intended "to betray the soul of that hemiplegia or paralysis which many consider a city" (Gilbert, 1957: 55). Joyce believed that the individuality of the inhabitants of Dublin had been subsumed in a religion whose moral, political and cultural influence denied them any opportunity to make choices for themselves (Childs, 2001: 202; Davies, 2001: vil). He felt that the attitude of the mass of

\footnotetext{
' The Irish Ireland movement is a collective name for the various organisations active in the field of Irish cultural nationalism in the late nineteenth and early twentieth centuries (http://multitext.ucc.ie/d/Irish_Ireland).
} 
Irishmen towards their religion was, in the words of Stephen Dedalus, that of "a dullwitted loyal serf." (Joyce, 1991: 139). Using Stephen as his mouthpiece, Joyce attacks notions of "essentialised collective identity" as being over simplistic, whether derived from Roman Catholicism or from any other form of retrogressive construct (Mulrooney, 2001). Stephen Dedalus' declaration in Joyce's Ulysses that "History ..... is a nightmare from which I am trying to awake" has been linked with Marx's description of history as "the tradition of all the dead generations that weighs like a nightmare on the brain of the living" (Harding, 2003: 119). At the end of A Portrait, the young artist sets out to escape that nightmare, - "to forge in the smithy of my soul the uncreated conscience of my race" (Joyce, 1991: 196). Stephen Dedalus' attempt to take flight as an artist away from the cultural and spiritual labyrinth of Dublin recalls Howe's assertion that the Modernist writer disdains "the mass, the mire, the street" and "exits from history into the self-sufficiency of art" (cited in Brooker, 1992: 10). Joyce was also influenced by the ideas of the philosopher Nietzsche, both in terms of the attack he made on religion and of the importance he assigned to the individual mind, as opposed to the mindless 'herd'. In Thus Spoke Zarathustra (1883-85), Nietzsche famously proclaimed that "God is dead" (Nietzsche, cited in Childs, 2000: 55). Morality was, therefore, revealed as simply a means to consolidate power. Ethical beliefs were no more than a construct derived from the instinct of the herd to gain strength in numbers (59-60). Nietzsche went on to argue, in his Essay in Self-Criticism (1886), that the metaphysical activity of mankind should be art rather than morality since the existence of the world could only be justified as an aesthetic phenomenon (55). Given that social, political, philosophical and moral systems were externally-imposed, artificial, empty constructs, the artist must speak for himself, as an individual (60). This is precisely what Stephen Dedalus himself chooses to do. Although he acknowledges the logic 
and coherence of the philosophical and moral system of Catholicism, and its apparent solidity, underpinned as it is by "twenty centuries of authority and veneration", ultimately Stephen rejects Catholicism as an absurdity (Joyce, 1991: 188). In Eco's view, modernism wished to abolish the past, and from this perspective he sees A Portrait as "an attempt at the modern" (Eco, 1992: 225-227). As a modern artist, Stephen will strive to detach himself "from the constraints of routinised cognition and everyday action" (Habermas, 1992: 133). He resolves to seek, through art, "the loveliness which has not yet come into the world" Joyce, 1991: 194).

For writers such as Joyce, influenced by Freud's work on psychoanalysis, there was no such thing as a stable normative self to which everyone might conform; rather, the self was "evolving, fluid, discontinuous and fragmented" (Childs, 2000: 51). So, in A Portrait, key moments in Stephen Dedalus' emotional, spiritual and aesthetic development are given as a "fluid succession of presents" (Mitchell, 1976: 70), through which what Joyce calls "the curve of an emotion" is drawn out, culminating at the point where Stephen affirms his identity as a young artist (Epstein, 1971: 102-103). To reach this point, Stephen has had to change: "I was someone else then .... I was not myself as I am now, as I had to become" Joyce, 1991: 185). Stephen makes this claim during a discussion with his friend Cranly, in which he admits that he had believed in religion while at school, but that he has now lost his faith. Although Stephen acknowledges the influence of his background upon his individuality - "This race and this country and this life produced me ..... I shall express myself as I am" (156), he has come to recognise the renunciation of religion as a key element in the emergence of his artistic identity.

In the light of the above, the remainder of this paper will examine the pivotal role played by religion in the construction of Stephen's identity in the course of his 
childhood, adolescence and transition into young adulthood. It will also consider the extent to which the text substantiates the claim of the young artist to have freed his soul from the constraints of religion.

Nationality, language, religion, the "nets" (157) which enclose Stephen as a child and adolescent, are in fact inextricably intertwined, with religion as the central strand. Religion permeates his home life, his induction into the adult world of Irish politics, his school life, his expectations for the future, much of the literature he reads, and even the language with which he expresses himself.

An understanding of the interrelationships between Catholicism, family life, guilt, fear and punishment is indoctrinated into Stephen from an early age. As an infant, he says that he will marry Eileen, a Protestant. The reaction is unfavourable. By hiding under a table, the child manifests his awareness of culpability, even if he does not yet fully understand his crime. Similarly, acceptance of the intellectual authority of the Church has been instilled into the child by a very young age. The boy has learned that Dante is a clever and well-read woman, but at the same time he believes that "Father Arnall knew more than Dante because he was a priest" (6).

The image of home as a haven of security and certainty, which sustains Stephen during the lonely torment of his early schooldays at Clongowes, is shattered by the argument over the role played by the Catholic clergy in the downfall of Parnell, which ruins his first Christmas dinner with the adults. What should have been a happy milestone in Stephen's development leaves him "terrorstricken" and confused about the relationship between politics and religion (29). On the other hand, as he matures and gains a clearer understanding of the fate of Parnell, and others like him, who devoted their lives to their cause only to be betrayed with the complicity of the Catholic clergy, Stephen, who was himself named after a martyr (123), begins to identify to some extent with Parnell. Recalling the 
dream of dying which he experienced during his confinement in the infirmary at Clongowes, and which coincided with the death of Parnell, Stephen reflects: "But he had not died then. Parnell had died" (70). Enlightened by Parnell's fate, Stephen refuses to sacrifice his individuality to the cause of narrow Irish nationalism, dissociates himself from an Ireland that he describes as "the sow that eats her farrow" (157), and concludes that he can only realise his identity as an artist abroad.

The undermining of Stephen's confidence in the priesthood, which begins at the Christmas dinner table, is exacerbated by the cruel and arbitrary punishment he receives at the hands of Father Dolan when he accidentally breaks his glasses at Clongowes. However, his faith in clerical authority and in justice is restored by the Rector's apparently sympathetic response to his complaint. He resolves that, despite his triumph, he will continue to be "quiet and obedient" (44). He will not commit the sin of pride. However, some time later, when he is about to be enrolled at Belvedere, Stephen learns from his father that the Rector had regarded the whole incident as a joke (Joyce, 1992: 54). This is the first instance in the novel of a pattern in which moments of spiritual elevation are followed by episodes of deflation (Belanger, 2001: XV-XVI).

At Belvedere, Stephen stands somewhat apart from his fellows, apparently a "saint" and a "model youth" (58), isolated by his habit of introspection and his bookishness, yet at the same time, paradoxically, surrounded by discourse. The voices of his family, his teachers, his friends and his compatriots call upon Stephen to conform to various pre-conceived notions of what his identity should be. However, their din is "hollow-sounding", and they succeed only in leaving him confused and irresolute about his destiny. The call to be a good Roman Catholic is pre-eminent, but Stephen's emergent sexuality and his immersion in the works of subversive writers breed unrest and bitter thoughts, which compound his growing 
scepticism about the religious life, until he is accused of writing a heretical essay (59).

During a trip to Cork, Stephen is mortified by his perception of his father's weaknesses and sickened by the urgings of his own flesh. He feels that he has "put himself beyond the limits of reality" (70). He repeats his name over and over again, as if in a desperate attempt to keep hold of the identity which now eludes him, his identity as an innocent child: "He had been lost or had wandered out of existence for he no longer existed" (70).

Academic success becomes a means to construct a new identity. Prize money provides a means to alleviate his family's poverty, to transcend the sordid reality of his inner and outer existence "by rules of conduct and active interests and new filial relations" (74). However, the prize money is soon spent and Stephen perceives the futility of his efforts. Again a brief moment of triumph has been succeeded by a fall. Stephen remains isolated from his family by his inner turmoil. Physical desire alienates Stephen from the life around him and from the rules of the religion which had helped shape his earlier identity.

Stephen, who had once conceived of love in spiritual terms as a "holy encounter" in which he would lose his weakness, timidity and inexperience (75), now seeks transcendence through $\sin$. In the arms of a prostitute, Stephen is recreated as "strong and fearless and sure of himself" (77). Once again, however, the moment of epiphany, of transcendent awareness, is succeeded by cold reality. Brief moments of ardour with prostitutes are succeeded only by a continued awareness of the squalor of his existence and "a cold indifferent knowledge of himself" (78-79). Conscious that his every sin multiplies his guilt and that he faces eternal damnation, Stephen is unable to repent. However, he retains the shell of his former identity, continuing in his prefecture of the sodality of the Blessed Virgin Mary at college. 
This apparent hypocrisy at the same time suggests that the religious impulse remains alive in Stephen, for in Catholic doctrine Mary is the refuge of sinners, and signifies the possibility of intercession and redemption.

Onto this fertile ground fall the words of Father Arnall's sermons during the three day religious retreat at Belvedere. Here, Stephen experiences a crisis of conscience that is "Irish and Catholic in its terror, its ardour and its intensity" (Martin, cited in Mulrooney, 2001). The awareness of religious authority, the notions of $\sin$ and guilt, and the terror of punishment which had been indoctrinated into Stephen from his earliest formative years are resurrected and reinforced. The prospect of an eternity of physical and spiritual torment in hell is set against the prospect of repentance and divine mercy. Stephen suffers agonies of terror, guilt and shame. Stephen feels that the very core of his being has been exposed: "The preacher's knife had probed deeply into his disclosed conscience" (Joyce, 1992: 88). He is humiliated by his fall, weeps for his lost innocence, and resolves to confess his sins truly and repentantly so that he might again be at one with God.

The cleansing process of confession allows Stephen to index his identity once again to the fixed doctrines and practices of the Catholic Church, which allow "little room for identity-as-process" (Mulrooney, 2001). The pattern of his day is determined by devotional routines; his senses are rigorously disciplined and mortified. In his new life of piety, Stephen so far transcends the material and the sensual that he comes to question the very need for his existence as a human being (115). Inevitably, however, Stephen is unable to sustain this level of spiritual exaltation. He finds himself at the mercy of minor imperfections and irritations, culminating in the realisation that his life of devotion is inherently sterile. The return of physical desire, accompanied by feelings of guilt, causes Stephen to doubt the sincerity and validity of his repentance (116-118). 
At this point in his intellectual and spiritual development, Stephen begins to question the judgment of his Jesuit masters at Belvedere. He experiences the sensation that he is "slowly passing out of an accustomed world ..... hearing its language for the last time" (120). However, it is also at this point that Stephen is asked to confront the question of whether he wishes to dedicate himself to that very world. Religion offers Stephen another opportunity to transcend the squalor of his daily life and home environment by assuming the priestly identity he had often taken in his proud and secret imaginings. Stephen is tempted by the secret knowledge and the power of the priesthood, by the opportunity to stand aloof, sinless, engaged in sacrificial and sacramental acts, free from material cares. However, the thought of the passionless nature of such an existence repels him. He understands that his destiny lies apart from what he had hitherto imagined to be his sanctuary but now realises would require the sacrifice of his individuality.

Having rejected the call to a religious life, Stephen experiences another of the epiphanies, or sudden moments of revelation, which mark each climax in his search for identity (Childs, 2001:199). As he hears his surname called aloud by his friends, Stephen recognises the prophetic quality of its association with Daedalus, "the fabulous artificer", who took flight from the Labyrinth, with his son Icarus, on wings of his own devising. He experiences a vision of "the end he had been born to serve and had been following through the mists of childhood and boyhood Joyce, 1992: 130). The vision is confirmed by the actual presence of a beautiful, bird-like girl in the sea. He will forge a new identity as an artist: "To live, to err, to fall, to triumph, to recreate life out of life!" (132).

Paradoxically at the very moment of rebirth, Stephen expresses his sense of release from the fear and guilt associated with Catholicism in terms of death and resurrection. He continues to employ the discourse of the religion whose call he has 
renounced: "His soul had arisen from the grave of boyhood, spurning her graveclothes" (130). Likewise, in his search for the essence of beauty, Stephen turns not only to Aristotle but to the scholastic philosopher Aquinas, one of the fathers of the Church (126). Similarly, in propounding his aesthetic theory, Stephen likens the dramatic artist to "the God of creation, (who) remains within or behind or beyond or above his handiwork, invisible, refined out of existence, indifferent, paring his fingernails" (166). Later, drawing upon the liturgy of the Eucharist for his metaphor, Stephen describes himself as "a priest of the eternal imagination, transmuting the daily bread of experience into the radiant body of everliving life" (170). He employs similar imagery in his villanelle (172). In other words, although Stephen has denied the call to the priesthood and lapsed from religious practice, the language with which he seeks to construct his new identity remains, as Cranly puts it, “supersaturated" with Catholicism (185).

In the course of A Portrait, Stephen seeks to define his own identity. However, he is repeatedly confronted and confounded by the influence of his environment, and in particular his cultural and religious heritage. At the end of the novel, Stephen resolves to escape the constraints of family, narrow nationalism and religious tradition by moving abroad. He proclaims that he has found his identity as an artist. Indeed he assumes artistic control of the narrative through the agency of his diary. However, the "confessional lyricism" of the diary, in the phrase coined by Mulrooney (2001), reveals that Stephen is still at the first stage of artistic development, as defined by his own theory of aesthetics. He has yet to refine himself, and his Catholic past, out of existence. Therefore, the question of the extent to which Stephen will succeed in his aspiration to forge the uncreated conscience of his race remains open. The repeated pattern of flight followed by fall woven throughout the narrative structure of the novel may continue, or it may have 
been broken. Will Stephen fall, like Icarus, weighted down by history and tradition; or will he succeed in breaking wholly free of family, church and nation, and soar, like Daedalus, to new heights of creation?

\section{Works Cited}

Belanger, Jacqueline. (2001). "Introduction". In A Portrait of the Artist as a Young Man. Ware: Wordsworth Editions.

Brooker, Peter. (Ed.). (1992). Modernism/Postmodernism. London: Longman.

Childs, Peter. (2000). Modernism. London: Routledge.

Davies, Laurence. (2001). “Introduction”. In Dubliners. Ware: Wordsworth Editions.

Eco, Umberto. (1992). "Postmodernism, Irony, the Enjoyable". Modernism/Postmodernism. Ed. P. Brooker. London: Longman. 225-228.

Ellmann, Richard. et al. (1984). Light Rays: James Joyce and Modernism. Ed. E. Heyward. New York: New Horizon Press.

Epstein, Edmund L. (1971). The Ordeal of Stephen Dedalus: The Conflict of the Generations in James Joyce's a Portrait of the Artist as a Young Man. Carbondale, IL: Southern Illinois University Press.

Gilbert, Stuart. (Ed.). (1957). Letters of James Joyce. New York: Viking Press.

Habermas, Jürgen. (1992). "Modernity - an Incomplete Project". Modernism/Postmodernism. Ed. P. Brooker. London: Longman. 125-138.

Harding, Desmond. (2003). Writing the City: Urban Visions \& Literary Modernism. New York: Routledge.

Joyce, James. (1991). A Portrait of the Artist as a Young Man. Ware: Wordsworth Editions.

Mitchell, Breon. (1976)."A Portrait and the Bildungsroman Tradition". Approaches to Joyce's Portrait: Ten Essays. Ed. T.F. Staley, and B. Benstock. Pittsburgh: University of Pittsburgh Press. 61-73.

Mulrooney, Jonathan. (2001). "Stephen Dedalus and the Politics of Confession." Studies in the Novel 33.2: 160. <http://www.questia.com/PM.qst?a=o\&d=5001024623>. 